\title{
Basal cell carcinoma on nickel dermatitis after leech applying
}

S. Shamsaddini' and S. Dabirit

\section{Introduction}

Chronic nickel dermatitis, like other longterm lesions, can degenerate into basal cell carcinoma (BCC) $[1-2]$. Leaving the leech jaw in the lesion after leech application can cause malignancy. When a single mechanical injury to normal skin is followed by carcinoma, the wound often heals slowly, breaks down repeatedly or does not heal at all. The neoplasm is nearly always a BCC [3-10].

Hirudiniasis is an internal or external insidious infestation by bloodsucking leeches. Following biting and sucking of blood from the host animal, certain rare complications may occur [11]. The most notorious species of the genus is Limnatis nilotica [12,13], which lives in brooks, streams, ponds and freshwater lakes in southern Europe, north Africa and western Asia including the Islamic Republic of Iran [10]. Leech application (artificial infestation) has been used throughout history.

$\mathrm{BCC}$ is usually seen on ulcer scars, on skin damaged by ultraviolet light, bacille Calmette-Guérin (BCG) vaccination scars, tattooed skin and on skin adjacent to leg ulcers. Chronic eczema, lichen simplex chronicus and other ulcers can also give rise to malignancy. This is a case study of $\mathrm{BCC}$ after traditional therapy with leech application on a solitary lesion of chronic nickel dermatitis.

\section{Case report}

A 96-year-old woman was seen at her home for an ulcer with a very large serpiginous margin on the anterior surface of her neck that had not improved after leech application approximately 2 years previously. She had suffered from a chronic pruritic lesion on her jowl at the site where she had continuously used a nickel pin in her kerchief. This had continued for 5 years, with periodic improvement after using glucocorticosteroid ointments. Due to seyere recalcitrant pruritus, she resorted to the traditional therapy of using direct leech application on the surface of the plaque. The leech sucked the blood through the lesion for 6 hours, after which it was forcibly removed. Prolonged bleeding was experienced for many days. The opening of the leech bite did not improve, and instead developed a very large serpiginous margin. The size of the ulcer gradually increased to $12.28 \mathrm{~cm}$.

The primary site of leech application was the midline of her jowl. The ulcer extended to the right side of the jowl, affecting all of the ipsilateral ear area. More

'Kerman University of Medical Sciences, Kerman Darman Hospital, Kerman, Islamic Republic of Iran. Received: 13/08/98; accepted: 23/02/99 


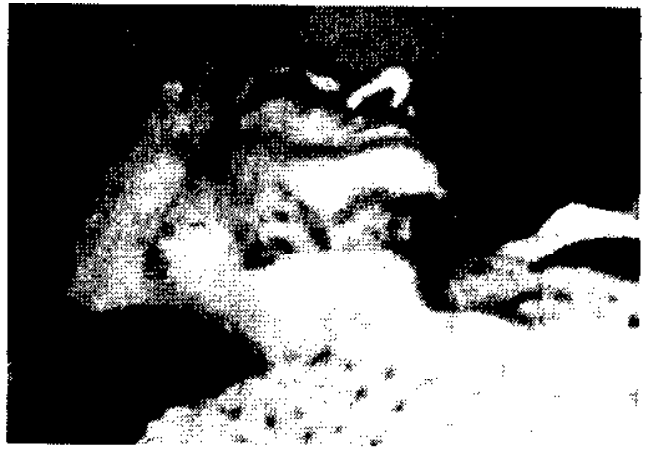

Figure 1 Chronic ulcer on nickel dermatitis after leech application

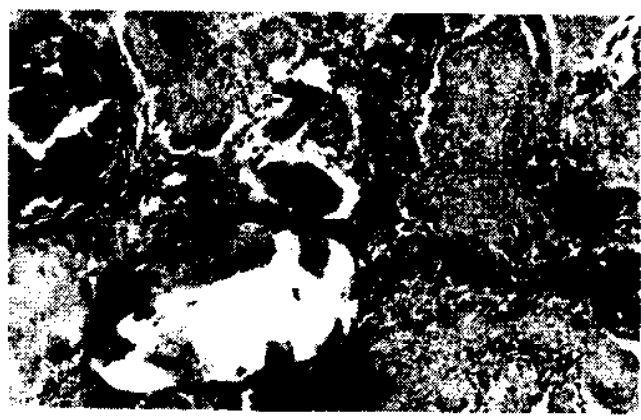

Figure 2 Histopathological section of basal cell carcinoma of mandibular chronic ulcer after leech application

evaluation and general examinations for underlying disease, such as diabetis mellitus and hypercholesterolaemia were negative (Figures 1 and 2).

\section{Discussion}

When a leech attaches to and bites the host's skin or mucous membrane, it firstly secretes an anticoagulant (hirudin) from its salivary gland. Trauma resulting from the leech bite and from the leech jaw remaining in the lesion after its forcible removal can predispose the lesion to malignancy. Hirudin specifically inhibits thrombin in the clotting process, causing continuous bleeding even after the leech has dropped off or been removed $[13,14]$. Continuous bleeding may also result from the histmaine-like substances secreted by the leech to prevent closure of capillaries $[12,14]$. The leech also excretes a local anaesthetic that allows it to bite and suck the blood without causing pain to the host [15].

In this case, the traditional therapy of applying leeches directly over a plaque of nickel dermatitis induced a BCC. The leech did not drop off itself; the patient had to temove it from the skin by force. Bleeding continued for many days and the site of the leech bite ulcer did not improve. Other leech bite complications include bullac, haemorrhage, pruritus, wheal formation, necrosis, bleeding and ulceration [5].

Necrosis with chronic progressive ulcer can be due to the leech bite toxin or to the antigens that exist in its saliva, or to a foreign body reaction against the leech jaw [5], which usually remains in the person's body when the leech is forcibly removed. Leech application can also cause the person to be infected by Mycobacterium marinum, a parasitic species more usually hosted by salt-water fish, or by Aeromonas hydrophila, which leeches carry in their gut [4]. However, paraclinical investigations and pathological biopsy results showed no significant findings concerning either of these organisms or deep fungal infection. A biopsy specimen from the marginal lesion revealed $\mathrm{BCC}$ of unknown cause. $\mathrm{BCC}$ has never been reported after leech application, but trauma and ehronic cezema can induce it. Because of the risk to this patient of systemic anaesthesia and the spreading of her uleer, surgery was not possible. She con- 
sented to conservative therapy, but 6 months later died suddenly after a cardiac arrest.

\section{Conclusion}

Chronic eczematous lesions can progress to $\mathrm{BCC}$ especially when a foreign body has been left in the lesion. Other mechanical traumas, such as leech bites and chronic ulcer scarring and thermal burns can favour the development of BCC. This is a case of chronic nickel dermatitis with coincidental leech application (a traditional therapy method) causing BCC.

\section{References}

1. Harry LA, Richard BO, William DJ. In: Andrews' diseases of the skin: clinical dormatology, 8th od. Philadelphia, WB Saunders Company, 1990:771-3.

2. Briggs JG. The role of trauma in the etiology of mallgnant melanoma: a revlew article. British journal of plastic surgery, 1984, 37:514-6.

3. Kennedy CTC. Reaction to mechanical and thermal injury. In: Champion RH, Burton, JL, Ebling FJG, eds. Textbook of dermatology, 5 th ed. Oxford, Blackwell Scientific Publications 1992.

4. Whitlock MR. The medicinal leech and its use in plastic surgry: a possible cause for infection. British journal of plastic surgery, 1983, 36:240-4.

5. Nopadon N. Hirudiniasis (leech bite). In Demi JD et al., eds. Clinical dermatology, 20th ed. Philadelphia, JB Lippincott Company, 1993.

6. Emmett AJJ, Broadbent G. Basal cell carcinoma in Queensland. Australian and New Zealand journal of surgery, 1981 51:576-90.

7. Rustin MH, Chambers TJ, Munro DD. Post-traumatic basal cell carcinomas. Clinical and experimental dermatology, 1984, 9:379-83.

8. Ewing MR. The significance of a single injury in the causation of basal cell carci- noma of the skin. Australian and New Zealand journal of surgery, 1971,41:1407.

9. Neuman Z, Ben-Hur N, Shulman J. Trauma and skin cancer. Plastic and reconstructive surgery, 1963, 32:649-56.

10. Noodleman FR, Pollack SV. Trauma as a possible etiologic factor in basal cell carcinoma. Journal of dermatologic surgery and oncology, 1986, 12:841-6.

11. Hoeppil R. Tang CC. Leeches in old Chinese and European medical literature. Chinese medical journal, 1941, 59:35978.

12. Payton B. History of medicinal leech applying and medical references. In: Muller KJ. Nicholls JG. Stent GS. eds. Neurobiology of the leech. Cold Spring Harbor, New York, Cold Spring Harbor Publications, 1981.

13. Chin TH. Further note on leech infestation in man. Journal of parasitology, 1949, 35:215.

14. Sawyer RT. Leech biology and behavior. In: Muller KJ, Nicholls JG, eds. Neurobiology of tho looch. Cold Spring Harbor, New York, Cold Spring Harbor Publications, 1981.

15. Stammers FMG. Observations on the behaviour of the land leeches (Haemadipsa). Parasitology, 1950, 40:237-40. 


\section{Book review} H.M. Kahssay, M.E. Taylor, P.A. Berman. Community health workers: the way forward.
World Health Organization, Geneva, 1998

In 1978 at the International Conference on Primary Hcalth Care in Alma-Ata, it was decided that health development should include social, economic and political upgrading; and it was recognized that community health workers (CHWs) had an essential developmental/promotional role by forming a link between the community and the first formal heath facility.

Moreover, it was agreed that in primary health care (PHC), avallability, accessibility, acceptability and affordability were basic principles, making $\mathrm{CHWs}$ a necessity in many countries. There are many examples of relatively successful CHW programmes, including the Chinese barefoot doctors who were trained as village doctors in the 1970 s and 1980s. In spite of the many country experiences, there still remain important areas in need of consideration and upgrading for $\mathrm{CHW}$ programmes to progress.

In 1990 a World Health Organization inter-regional meeting recommended the study of three themes that needed to be considered: altitudes of health personnel and communities towards $\mathrm{CHW}$; management and structure of health systems; and resource allocation.

The authors of this book have examined the three themes in an attempt to point out appropriate strategies to address them. In the course of doing so, they have analysed vertical relations between health personnel, communities and CHWs; changing attitudes; selection criteria; training curricula, methods and institutions and supervision and teamwork. Examples from Mexico, Zimbabwe, India and Costa Rica are described.

District health systems are identified as being the most appropriate to support PHC and the key to improving $\mathrm{CHW}$ programmes. The role of village health committees is not overlooked and health committee selections are discussed along with the use of community structures and groups (formal and informal), traditional healers, constraints and action required to overcome harriers

Since the provision of resources to CHWs is a recognized investment in the PHC system of most countries, the authors have been careful to cover aspects of necessary support services: planning, cost and budgeting and requirements of effective community involvement. In addition, the financing mechanism and the government, community and private sector roles are analysed, as well as resource allocation issues.

It is concluded that actual implementation and lesson-learning are the only ways to overcome problems of CHW programmes. This book provides a good guide, highlighting important areas of concern and pathways towards successful planning and implementation of a CIIW programme.

Amal E.M. Khairy

Senior Professor

Primary Health Care Section

High Institute of Public Health

University of Alexandria

Alexandria, Egypt 